\title{
RED BLOOD CELL SURVIVAL AFTER MANNITOL INFUSION: A CLINICAL STUDY IN HUMAN VOLUNTEERS USING $\mathrm{Cr}^{51 *}$
}

\author{
William Evers, M.D., M.SC., Gabor B. RaCZ, M.B., Cit.B. \\ and Edward G. Bell, M.D., PH.D.
}

TIFF WIDESPREAD CLINICAL USE of mannitol has brought an awareness of the changes it produces in haemodynamics, red blood cell morphology, haemoglobin-oxygen affinity, as well as intra- and extra-cellular $\mathrm{pH}$ and electrolyte shifts. ${ }^{1}$ Claims have been made that crenation and a decrease in mean corpuscular volume ( $\mathrm{MCV}$ ), together with rapid ionic exchanges, may affect the survival of the erythrocyte.

Mannitol is administered frequently during major surgical procedures, where considerable amounts of blood are lost and replaced.

The effects exerted by mannitol on haemodynamics. plasma volume, electrolytes, and on renal function, are well known. ${ }^{2-6}$ Much less information, however, is available on the influence of mannitol on the human erythrocyte, especially on its survival after the clinical use of the drug.

The morphology of the red blood cell changes rapidly when exposed to mannitol, be it in vitro or in vivo. ${ }^{1}$ The decrease in $\mathrm{MCv}$ is related to the concentration of mannitol and to the time of exposure. The red cell acquires the crenations also seen when it is bathed in other non-diffusable hypertonic solutions. ${ }^{3,7}$ These morphological changes are a result of marked ionic shifts occurring between the red blood cell and surrounding plasma, ${ }^{8}$ the salient features of which are cellular loss of water, $\mathrm{Cl}^{-}$and $\mathrm{K}^{+}$. As the water loss is proportionately greater than the shift of electrolytes, the reduction in cell volume may result in an increase in intracellular osmolality and $\mathrm{pH}$, as well as changes in membrane potentials. ${ }^{9}$

These morphological, chemical, and electrical changes may seriously interfere with the cell function and survival. ${ }^{10}$

In vitro studies showed that the addition of mannitol to blood or red blood cell suspensions does not seem to have a deleterious effect on the erythrocytes. If anything, mannitol slightly increases the electronegativity of the red blood cell, thus helping to avoid or reduce aggregation (sludging). ${ }^{9,11}$ Mannitol also has a protective effect when added to a red blood cell suspension subjected to mechanical agitation, i.e., it decreases the mechanical fragility of the erythrocytes. ${ }^{12}$ It also decreases haemoglobinaemia in the so-called "post-hypertonic haemolysis." 13 Banked blood shows no change in adenosine triphosphate (ATP) depletion ("storage disease") when exposed to mannitol. ${ }^{14}$

Only Roberts ${ }^{10}$ found increased clumping with increasing mannitol concentrations, but no change in mechanical or saline-osmotic fragility, despite incomplete morphological recovery of the red blood cell after removal from mannitol.

- From the Department of Anesthesiology and the Department of Radiology, State University Hospital, State University of New York, Upstate Medical Center, Syracuse, New York, 13210, U.S.A. 
One may argue that these studies involve data on immediate red cell survival and that long-term effects may not be so encouraging. ${ }^{15}$ The aim of our study was to investigate the influence of a rapidly administered dose of mannitol on the survival time of human erythrocytes.

\section{Material and Methods}

The subjects were ten healthy male volunteers (physicians and medical students). The red blood cells of each subject were labeled with $\mathrm{Cr}^{51}$ using sodium chromate and Strumia anticoagulant. ${ }^{16}$ Each subject received an intravenous injection of his labeled cells. During the ensuing two weeks, the radioactivity over the precordium, spleen and liver of the subject was measured, using an external scintillation detector. In addition, samples of venous blood were withdrawn to be used for the calculations of red cell survival.

The volunteer then received a rapid intravenous infusion of 25 grams of mannitol. The external counting and the venous blood sampling were carried out for an additional two-week period.

The red blood cell survival data was examined critically by statistical means to determine whether the survival half-time was affected by the mannitol infusion. The in vivo distribution data ${ }^{17}$ were evaluated to see if there was any splenic or hepatic enrichment occurring during the study, which would indicate sequestration of red cells in these organs.

\section{Labeling of Red Blood Cells}

Fourteen to $15 \mathrm{ml}$ of whole blood were withdrawn from a peripheral vein and added to a $20-\mathrm{ml}$ vacutainer tube containing $2 \mathrm{ml}$ of $\mathrm{NIH}$ Formula A acid citrate dextrose anticoagulant. $200 \mu \mathrm{Ci}$ of $\mathrm{Cr}^{51}$ as sodium chromate was added to the tube and gently inverted to mix the contents thoroughly. The reaction time was 15 to 20 minutes, after which $1 \mathrm{ml}$ of fresh ascorbic acid solution $(500 \mathrm{mg} / \mathrm{ml})$ was added to the reaction vessel. The addition of the ascorbic acid reduced the hexavalent $\mathrm{Cr}^{51}$ sodium chromate to trivalent $\mathrm{Cr}^{51}$ chromic chloride and prevented any further labeling of red blood cells with $\mathrm{Cr}^{51} .{ }^{18}$ The labeled red blood cells were then washed three times with normal saline and re-suspended to the original volume with normal saline. The average labeling efficiency for the total series of volunteers was 84.8 per cent (range 79.0 to 88.6 ).

\section{In Vivo Distrubution}

The activity over the precordium, liver and spleen was measured by an external sodium iodide scintillation detector. The activities were measured six times in the first two weeks after injection of the labeled red blood cells, then six times in the two week period following the mannitol infusion.

It is recognized that a variable but significant degree of radioactivity over the liver and spleen is derived from the activity in the perfusing blood. The balance of the activity in each organ site is due to accumulation of the $\mathrm{Cr}^{51}$ label or the labeled red blood cells in that organ. Jandl ${ }^{17}$ stated that the precordial activity 
grossly parallels the activity of whole blood specimens and is thus due to perfusing blood. He, therefore, expressed the in vivo counts, in the liver and spleen, as a ratio of the radioactivity over the organ to that at the same time over the precordium. These organ-precordial ratios were felt to represent the quantity of $\mathrm{Cr}^{51}$ accumulated in the organ concerned.

Goldberg et al. ${ }^{19}$ in 1966 defined a new index, the "spleen-liver ratio" as a criterion of significant splenic sequestration of $\mathrm{Cr}^{51}$ labeled red blood cells. They compared this with the organ-precordial ratios and found a significant improvement in the assessment of those patients, with haemolytic anaemia, who would benefit from splenectomy. They concluded that a spleen-liver ratio which rises from $t_{0}$ to $t_{1 / 2}$ and is equal to or greater than 2.3 is indicative of splenic sequestration.

The splenic and hepatic activities in this study were cvaluated by the methods of both Jandl and Goldberg. Neither method indicated an abnormal accumulation of the labeled red blood cells in the spleen. The splenic-liver ratios for each patient are shown in Table II.

\section{Statistical Metions}

\section{Determination of Slopf of Bloon Activity Decay Curve}

The method of least squares was used to determine the best fit of the data for the regression of log activity of the blood samples versus time. The relationships of survival half-time to the slope of the line is $0.301 /$ slope where the activity is plotted as $\log _{10} .{ }^{20}$ The slope of the blood activity curve was determined for each patient before and after the mannitol infusion.

TABIE I

Tfest of Significance for Differences in Slopes of Pajred Samples for the Fntire Subject Group. Ho: $\mu d=0$

\begin{tabular}{cccr}
\hline Subject & $b_{1}$ & $b_{2}$ & $d_{\mathrm{i}}\left(b_{1}-b_{2}\right)$ \\
\hline 1 & 0.01344 & 0.01325 & +0.00019 \\
2 & 0.00736 & 0.01228 & -0.00492 \\
3 & 0.01228 & 0.00956 & +0.00272 \\
4 & 0.01177 & 0.01759 & -0.00582 \\
5 & 0.00901 & 0.01326 & -0.00425 \\
6 & 0.01254 & 0.01266 & -0.00012 \\
7 & 0.01365 & 0.01037 & +0.00328 \\
8 & 0.01395 & 0.01357 & +0.00038 \\
9 & 0.00957 & 0.01016 & -0.00059 \\
10 & 0.01652 & 0.00770 & +0.00882 \\
& & & $\vec{d}=-0.00031$ \\
\hline
\end{tabular}

\section{Test for Significance of Difference Between Slopes}

\section{Pre-Mannitol and Post-Mannitol}

Data was evaluated by a $t$ test using paired samples, ${ }^{21}$ Each pair of samples represcnted the slopes of the blood activity curve before and after mannitol for each individual ( Table I). 


$$
\begin{aligned}
& t=\frac{d}{S_{\bar{d}}} \\
& S_{\bar{d}}=\frac{\left(S^{2} d\right)^{1 / 2}}{n} \\
& S^{2}{ }_{d}=\frac{\sum\left(d_{i}-\bar{d}\right)^{2}}{n-1}
\end{aligned}
$$

$d_{i}=$ difference in slopes (pre- and post-mannitol for each subject (i))

$\bar{d}=$ average difference in slopes (pre- and post-mannital) for all subjects

$\bar{d}=-0.00031$

$$
\begin{aligned}
& S_{\bar{d}}^{2}=\frac{\sum\left(d_{i}-\bar{d}\right)^{2}}{n-1}=\frac{0.000173}{10-1}=0.0000192 \\
& S_{d}^{-}=\frac{\left(S^{2} d\right)^{1 / 2}}{n}=\frac{(0.0000192)^{1 / 2}}{10}=0.001386 \\
& t=\frac{\bar{d}}{S_{d}^{-}}=\frac{-0.00031}{0.001386}=-0.224 ; t_{\mathrm{tabu} \mathrm{lar}} 95 \% \text { conf. limits }=1.83 \\
& d . f .=n-1=9
\end{aligned}
$$

Conclusion: accept hypothesis that there is no difference in the slopes.

\section{In Vivo Counting Data}

\begin{tabular}{|c|c|c|c|c|c|c|c|c|c|c|}
\hline Day & 1 & 2 & 3 & 4 & 5 & 6 & 7 & 8 & 9 & 10 \\
\hline 2 & 0.90 & 0.58 & 1.10 & 0.78 & 1.28 & 1.12 & 1.15 & 1.07 & 1.12 & 1.13 \\
\hline 4 & 0.95 & 0.53 & 1.41 & 0.84 & 0.79 & 1.18 & 1.39 & 1.00 & 0.98 & 1.09 \\
\hline 7 & 0.74 & 0.46 & 1.81 & 0.56 & 0.97 & 1.12 & 1.18 & 0.91 & 1.04 & 1.48 \\
\hline 9 & 1.11 & 0.64 & 1.74 & 0.73 & 1.17 & 1.33 & 1.19 & 1.03 & 0.96 & 1.37 \\
\hline 11 & 0.85 & 0.63 & 1.32 & 0.76 & 1.16 & 1.13 & 1.44 & 1.02 & 1.46 & 0.80 \\
\hline 14 & 0.90 & 0.56 & 1.57 & 0.58 & 1.00 & 1.09 & 1.17 & 0.83 & 1.39 & 1.54 \\
\hline \multicolumn{11}{|c|}{ Mannitol infusion } \\
\hline 16 & 0.93 & 0.60 & 1.21 & 0.72 & 1.04 & 1.15 & 1.19 & 1.05 & 1.13 & 1.36 \\
\hline 18 & 1.04 & 0.75 & 1.31 & 0.76 & 1.16 & 1.13 & 1.11 & 0.92 & 1.52 & 0.92 \\
\hline 21 & 0.83 & 0.63 & 1.82 & 0.55 & 1.09 & 1.15 & 1.09 & 0.77 & 1.11 & 0.98 \\
\hline 23 & 0.88 & 0.60 & 1.32 & 0.53 & 0.90 & 1.02 & 1.08 & 0.81 & 1.24 & 0.90 \\
\hline 25 & 0.82 & 0.88 & 1.77 & 0.83 & 0.86 & 1.19 & 1.09 & 0.96 & 1.64 & 1.08 \\
\hline 28 & 0.80 & 0.52 & 1.62 & 0.58 & 0.94 & 0.94 & 1.35 & 1.12 & 0.98 & 1.09 \\
\hline
\end{tabular}

The ratio of the splenic activity on each day of the study was normalized with respect to the hepatic activity on the same day. This is shown for each subject. (Table II).

TABLE II

In Vivo Counting Data: The Splenic Activity on each Day is Normalized with Respect to the Liver activity on That Day. This is Shown for Each Subject

\section{Results}

1. Mannitol did not affect the survival half-time of the $\mathrm{Cr}^{51}$ labeled red blood cells ( 95 per cent C.L.). The average survival half-time for the 10 subjects was 22.0 
days before Mannitol administration and 23.6 days after. Normal survival halftime is greater than 20 days.

2. There was no indication of abnormal organ localization due to alteration of the labeled red blood cells by the Mannitol infusion.

\section{Discussion}

The majority of authors investigating the possible effects of Mannitol on the human erythrocyte in vitro believe that no immediate damage can be demonstrated.

Under clinical conditions, one would be concerned that the irregular surfaces of crenated red cells would offer more resistance to flow as the elastic deformability of the erythrocyte is decreased. ${ }^{22}$ This, in turn, would expose the cell to greater mechanical stress. Finally, prolonged hypertonic stress may produce not only the transient "cellular hyperviscosity syndrome" but also cellular rigidity (sclerocythaemia). ${ }^{15}$ If such were the case, one would expect that these cells would be more quickly removed from the circulation as they could not pass easily through the sinusoids of the spleen (splenic sequestration).

Results of recent clinical studies, however, seem to point toward a beneficial effect of mannitol on red blood cell integrity and survival. Several authors have found that it decreases haemolysis during extracorporeal circulation. ${ }^{23,25}$

It appears from our study that the long term survival of the human erythrocyte is not adversely affected by the usc of average doses of Mannitol.

\section{SUMMARY}

The red blood cells of ten healthy human volunteers were labeled with $\mathrm{Cr}^{51}$ and their survival time was studied before and after the injection of $25 \mathrm{~g}$ of Mannitol in $500 \mathrm{ml}$ of Dextrose in water. Mannitol did not affect the survival half-time of the red blood cells in the subjects tested.

\section{ACKNowledGement}

The technical assistance of Miss Alma McGonigal, R.T., is gratefully acknowledged.

\section{RÉSUMí}

Les globules rouges de dix volontaires on été marqués avec le Chrome ${ }^{51}$ afin de déterminer les effets du Mannitol sur la survivance d'érythrocytes d'homme.

La demi-vie des hématies été de 22 jours avau.t l'injection du Mannitol et 23.6 utilisant le compteur Picker "Omniprobe") pendant deux semaines avant et deux semaines après l'injection intraveineuse rapide de $25 \mathrm{~g}$ du Mannitol.

La demi-vie des hématies été de 22 jours avant l'injection du Mannitol et 23, 6 après. Les comptes de l'activité radioactive sur la rate, le foie et le précordium n’ont par montré des differences du dépérissement isotopique appréciables.

Nous pouvons donc conclure que malgré les altérations morphologiques et électrolytiques des érythrocytes, le Mannitol n'affecte pas la survivance (demivie) des globules rouges d'homme. 


\section{REFERENCES}

1. Lilien, O. M. \& ANdaloro, V. A. Mannitol and Ionic Shifts. Invest. Urology, 7: 467-477 (1970).

2. Dominguez, R.; Corcoran, A. C.; \& Page, I. H. Mannitol Kinetics of Distribution, Excretion and Utilization in Human Beings. J. Lab. Clin. Med., 32: 1192-1197 (1947).

3. Lilien, O. M.; Jones, S. G.; \& Mueller, C. B. The Mechanism of Mannitol Diuresis. Surg. Gyn. Obstet., 117: 221-228 (1963).

4. Seitzman, D. M.; Mazze, R. I.; Schwartz, F. D.; \& Barry, K. G. Mannitol Diuresis: A Method of Renal Protection During Surgery. J. Urol, 90: 139-143 (1963).

5. Berger, B.; Evers, W.; \& Mueller, C. B. Mannitol Induced Diuresis in Hydropenic Men. Surgery, 64: 381-386 (1968).

6. Hostnik, W. J.; Powers, S. R., Jr.; Boba, A.; \& Stein, A. A. Observations on the Effect of Mannitol on Renal Hemodynamics and $\mathrm{O}_{2}$ Tension in the Urine and Renal Vein. Surg. Forum, 10: 872-875 (1959).

7. Larcan, A.; Stremff, F.; Peters, A.; Genetet, B.; \& Helmer, J. Effets de differents solutés glucidiques sur la viscosité sanguine, la vitesse de sedimentation et la morphologie des globules rouges. Path. Biol., 6: 397-402 (1968).

8. Lit.ien, O. M. \& ANdalaro, V. A. Mannitol and Ionic Shifts. Investig. Urology, 7: 467477 (1970).

9. Castaneda, A. R.; Bernstein, E. F.; \& Varco, R. L. The Effect of Polyvinylpyrrolidone, Mannitol, Dextrose and of Various Dextrans on Red Blood Cell Charge. Bibl. Anat. 7: $262-266$ ( 1965$)$.

10. Roberts, B. E. \& SMrth, P. H. Hazards of Mannitol Infusions. Lancet, 2: 421-422 (1966).

11. Bjork, V. O.; Itotr, F.; Nordlund, S.; \& Sotomayer, L. The Effects of Ascorbic Acid and Mannitol on Induced Red Blood Cell Aggregation. Acta Chir. Scand. Suppl., 356: 95-99 (1965).

12. Esposito, S. \& Vercillo, L. Ricerche sulle Proprieta biologiche delle soluzioni di Mannitolo. La resistenza meccanica degli eritrociti in sospensione in soluzioni di Mannitolo. Riv. Emoter. Immunoemat., 9: 259-263 (1962).

13. Zade-Oppen, A. M. M. The Effect of Mannitol, Sucrose, Raffinose and Dextran on Posthypertonic Hemolysis. Acta. Physiol. Scand., 74: 195-206 (1968).

14. Beutler, E. \& Duron, O. Studies on Blood Preservation. The Relative Capacities of Hexoses, Hexitols, and Ethanol to Maintain Red Cell ATP Levels during Storage. Transfusion, 6: $537-542(1966)$.

15. WeLts, R. Syndromes of Hyperviscosity. New Engl. J. Med., 283: 183-186 (1970).

16. Cooper, M. and Owen, C. A. Labelling Human Erythrocytes With Radiochromium. J. Lab. \& Clin. Med., 47:65 (1956).

17. Jande, J. H.; Greenberg, M. S.; Yonemoto, R. H.; \& Castle, W. B. Clincal Determination of the Sites of Red Cell Sequestration in Hemolytic Anemia. J. Clin. Invest., 35: 842 (1956).

18. READ, R. C. Studies of Red Cell Volume and Turnover Using Radiochromium; Description of New "Closed" Method of Red Cell, Volume Measurement. New England J. Med., 250: 1021 (1954).

19. GoldberG, A.; Hutchinson, H. E.; \& MacDonald, E. Radiochromium in the Selection of Patients with Haemolytic Anemia for Splenectomy. Lancet, 1: 109 (1966).

20. Aufderheide, A. C. Radiochromium in the Estimation of Survival of RBC. Review of the Literature. Amer. J. Clin. Path., 34: 258 (1960).

21. Dunn, O. J. Basic Statistics: a Primer for the Biomedical Sciences, Chapter 7, p. 72. Wiley \& Sons, Inc. N.Y. (1964).

22. Rand, P. W. \& Lacombe, E. Hemodilution, Tonicity and Blood Viscosity. J. Clin. Invest., 43: 2214-2226 (1964).

23. O' NeIll, J. A., Jr. \& Collins, H. A. The Effect of Various Blood Additives on Hemolysis during Extracorporeal Circulation. Ann. Thorac. Surg., 1: 769-774 (1965).

24. Porter, G. A.; Sutherland, D. W.; McCord, C.; Starr, A.; \& Griswold, H. E. Prevention of Excess Hemolysis during Cardiopulmonary Bypass by the use of Mannitol. Circulation, 26: 773-774 (1962).

25. Porter, G. A.; Sutherland, D. W.; McCord, C. W.; Starr, A.; Griswold, H. W.; \& KINSEY, J. Prevention of Excess Hemolysis during Cardiopulmonary Bypass by the Use of Mannitol. Circulation, 27: 824-827 (1963). 